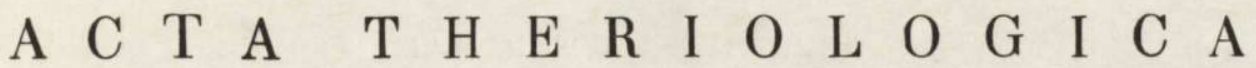 \\ VOL. XII, 22: $339-348$ \\ BIAŁOWIEŻA \\ 30.XII. 1967
}

\author{
Kazimierz KR Y S I K \& Krzysztof S W I E Ż Y N S K I

\section{The Present State of Research on the Morphology of the European Bison}

\section{Bisoniana XVIII}

\begin{abstract}
The article contains a review of studies on the anatomy of the European bison, arranged in chronological order. Up to 1949 literature on this subject was formed in the majority of cases by contributions dealing mainly with the elements of the skeleton which were more accessible. A more detailed discussion is given of studies carried out in the European Bison Research Centre attached to the Department of Animal Anatomy, Warsaw Agricultural University. Studies made during the period from 1960-1966 are presented, including those not hitherto published dealing with the blood-vascular system, the integumentary system and the spinal nerves. Studies on the alimentary tract and the urogenital system are nearing completion. The results of these studies will be used for a monographic elaboration of the anatomy of the European bison.
\end{abstract}

The bison made what was probably its first appearance as an object of strict anatomical research at the turn of the 18th century in the study by J. E. Gilbert entitled "De Bisonte Lituanico" published in Vilnius in 1781 .

Nineteenth century morphological literature reports the results of research on this species in studies by B o j a n u s (1827), $\mathrm{S} \mathrm{k} \mathrm{i} \mathrm{ba} \mathrm{(1834),}$ $\mathrm{O}$ w e n (1848) and $\mathrm{M}$ üll e r (1852). The first two authors dealt with the skeleton of the European bison. The study by B o ja n u s, highly valued by the biologists of that time contained, in addition to a fairly detailed description of the skeleton, a section polemising with opinions held on the existence of Bos primigenius in historical times. The study may be considired as constituting a turning-point in research on the anatomy of the European bison, and as a signal drawing scientists' attention to this interesting species. $\mathrm{Ski}$ b a (1834), according to information given by Wilk us (1957), elaborated certain fragments of the skull. O we $\mathrm{n}$ (l. c.) and $\mathrm{M} \ddot{\mathrm{u}} \mathrm{ll}$ er (l. c.) described the structure of some of the internal organs of the European bison on the basis of the single examples at their disposal.

A commission was formed at the beginning of the 20 th century by the Piotrovsk-Razumovsk Agricultur Academy in Moscow to elaborate in detail the anatomy and biology of the European bison, but evente of subsequent years interrupted the implementation of that programme. The study by K u la g in (1929) on the microscopic structure of the ovaries of the European bison forms a distinct trace of the commission's activities.

During the period between the two world wars a few marginal studies appeared in various centres in Europe, forming evidence not so 
much of the greater interest being taken by morphologists in the European bison as the desire to make scientific use of the carcasses of a species so rare at that time.

Leithner (1927) included in his description of the skull of Bos primigenius a description of the skull of the European bison, emphasising the sex differences. J a nicki (1928) described the results of observations on the growth, sex dimorphism and specific characters on the basis of the skeletons of three European bison. Important corrections have been made to his conclusions as the result of research carried out in subsequent years.

$\mathrm{K}$ o c h $(1932,1934)$ had at his disposal very abundant material consisting of 53 skeletons, but considerable gaps in his documentation form a serious deficiency here. In the studies he successively published this author analysed the factors affecting changes in the postnatal development of the skeleton, including establishment of the age at which the epiphyseal cartilages disappear in different bones.

K rölling (1930) undertook an attempt at a specific description of these organs, using the parts of the male sex organs of one European bison at his disposel and the data given by $\mathrm{M}$ ülle r (l. c.)

The material used by Selahattin (1931) in elaborating the hair covering in some representatives of Bovidae included samples of hair taken from two European bison. P o l e in er (1931) wrote a Ph. D. theses, the material for which was formed by two limbs of a female European bison which had died in the Vienna Zoo. He gives an exact description of the skeleton, musculature and main vascular and nerve trunks, and also compares the results obtained with the structure of the limbs of cattle. Many of the statements given by P ol e in e r (l. c.) find no conformation in later research carried out on more numerous, and therefore more representative, material. That same year F l e r ov (1932) published a study on the differences in the integumentary system of European bison from the Caucasus region an from Białowieża, having abundant material in the form of 88 hides at his disposal.

After the second World War, apart from the Warsaw Centre (which will be discussed later on) very few publications appeared on the anatomy of the European bison. A l b r e ch t (1944) dealt with the heart structure of some Bovidae, and he also had the heart of one European bison among his material. Millot (1945) described the skeletons of European bison in the Natural History Museum in Paris. Z a rzycki (1957), using sections from several of the internal organs of the bison "Punkt", described their histological structure. S ok ol ov (1963) examined 7 speciens of male hybrids of European and American bison, in which the European bison strain greatly predominated, in respect of their integumentary system. He described the histological structure of the skin, epidermis, glands and hair.

The State Council for Conservation of Nature, exercising general supervision, over the Europaen bison in Poland, belongs to the Ministry of Forestry and Woodworking Industries. In 1949 senior author (K. K.) reached an agreement with this Ministry and organized a European bison Research Centre in Department of Animal Anatomy of Warsaw Agricultural University. The chief aim of the Centre is to collect and pre- 
serve European bison material and to carry out successive research work, the results of which will permit of elaborating a monograph on the anatomy of the European bison. The value of the research is the greater in view of the fact that we have at our disposal a relatively large number of individuals of known origin, and not single specimens. The material in the Centre's possession is also at the service of other institutions interested in the work, in particular the Departments of Animal Physiology of Warsaw Agricultur University and Warsaw University, and the Departments of Pathological Anatomy, Epizoootiology, Internal Diseases of Animals and Parasitology of the Veterinary Faculty of Warsaw Agricultural University. In addition several scientific centres outside Warsaw co-operate with the Centre.

The study by K rysiak (1960) contains a section which sums up the work carried out by the Centre up to 1959. During this period 8 anatomical studies were published, which were discussed in detail in the above-mentioned paper (K ry sia k, 1951 a, b; J uśk o, 1953; S w i eżyński \& Pilarski, 1956; Pilarski, 1956; Wilkus, 1957; Pilarski \& Roskosz, 1957; Piękoś, Pilarski \& Roskosz, 1958).

The next period of the Centre's activities, from 1960-1966, ended with the elaboration of 10 further studies, 7 of which have appeard in print. Perhaps the most noteworthy of these is the publication by the Centre of the translation into Polish by $€ u k$ a sik of the well-known work by B ojanus (1827) »De Uro nostrate eiusque sceleto commentatio". The work was elaborated and supplied with a commentary by members of the staff of the Department of Animal Anatomy, T. R o s$\mathrm{kos} z$ and W. E m pel (1965).

Manipulation of the enormous carcasses of the European bison and the necessity for making the utmost possible use of them gave rise to the idea of working out a cheaper and more effective method for their conservation (P i l a r s k i et al., 1967).

Osteological subjects predominate among the studies published. This state of affairs is explained by the fact that the skeleton of so large a mammal was far easier to keep that the soft parts of the carcass, and thus was preserved in museums and formed a supply of material for research. If certain of the subjects undertaken by the Centre appear to be repetitions of studies already made, it must be pointed out that the abundance of the material at our disposal enabled us to trace far more accurately the characters which we were investigating on the basis of far more numerous and documental material. The results which will now be discussed provide confirmation of this statement.

On the basis of the studies by Empel (1962), Roskosz (1962) and Empel \& Roskosz (1963), which took into consideration the results of earlier elaborations, the observations made on the s k le t o n of the European bison were as follows:

1. The most distinct specific characters of the skeleton of the European bison in comparison with domestic cattle are primarily located in the bones of the skull, then the scapula, pelvis and bones of the limbs.

2. The $\mathrm{number}$ of vertebrae in various parts of the vertebral column were most often: $C-7, T h-14, L-5, S-5$, Co -13 to 
16. The cervical part has of course a constant number of vertebrae, but shifts may occur in the other parts, although there is always a constant number of 24 vertebrae in the truncal part. The shifts in the number of vertebrae take the character of sacralisation of the lumbar vertebrae, lumbalization of the thoracic vertebrae or even sacralisation of the coccygeal vertebrae.

3. The majority of the linear measurements of the skuls increase markedly in the second and third year of life. The skulls of five-year old individuals of both sexes are similar to the skulls of adult animals. The legs usually cease growing after the age of five years is attained. After six years all the components of the long bones are joined by cssification. The epiphysis ossifies after the eighth year of life. Fusion of the bodies in the vertebrae of all sections of the vertebrae column begins at the age of six in the European bison of both sexes, and ends by the eighth year of life.

4. The sex dimorphism in the skeleton of the European bison is shown most clearly by measurement data. In the skull particularly distinct differences were found in the fornix, in the cornual processes and nuchal plane, chiefly in measurements of breadth. In the vertebral column dimorphism is most distinctly evident in the case of the cervical vertebrae. Measurements of the long bones, with the exception of the maximum length of the metacarpus and metatarsus, are greater in males than in females. The breadth-length index of the radial bones, metacarpus, metatarsus and phalanges I and II also exhibited sex differences.

Research on the skeleton of the European bison also supplied information on differences between European bison from lowland areas (Białowieża) and those belonging to the Caucasus line. The latter exhibit complete absence or very slight formation of the frontal eminence and a different shape of the mandible. The shift in number of vertebrae in the various parts of the vertebral column described previousły did not occur among individuals belonging to this line.

Among the skeletons examined many of the bones exhibit numerous deformations of a pathological character and the shift in number of vertebrae of different parts referred to above. They formed the object of detailed investigations, the results of which were published in two studies. Pilarski (1956) described deformations of six skeletons and stated that they were most often of traumatic origin and occurred mainly in the vertebral column. This suggests that for an animal with so great a body mass as the European bison the bone tissue is weak, althought it exhibits great regenerative power.

Pilarski \& Roskosz (1957) found in five of the 18 skeletons which they examined the phenomenon of sacralisation of the final lumbar vertebrae. It is significant that the females in which this irregularity occurred originated from the female named Planta-Fricki. The study provides a definite solution to the problem as to whether there is sex dimorphism in regard to the number of lumbar vertebrae in the European bison. J a n icki (1928) and J uśko (1953) both suggested the presence of such dimorphism.

Among the group of studies on the loc cmotory system, in addition to the skeleton, the skin musculature ( $\mathrm{S}$ wie żyński \& $\mathrm{Pi}$ - 
la rski, 1956) and skeletal musculature (Ś wieży ński, 1962) were also elaborated. In comparison with cattle and other domestic and wild ruminants, many of the muscles of the European bison exhibit characteristic morphological and topographical characters. Particularly important differences exist in the dorso-scapular region, and especially such muscular units as $m$. semispinalis capitis and $m$. semispinalis cervicis. Within the head region $m$. temporalis and $m$. biventer are particularly characteristic, while on the legs there are as many as 14 muscles which exhibit differences in relation to the corresponding muscles in cattle. Both the study by Krys i a k (1951) and Roskos z \& E mpel (1961) refute the view that the intensive development of procc. spinales of the initial thoracic vertebrae forming the characteristic hump on the dorsal line is connected with the great weight of the head. Observations of muscles also appear to argue against this opinion. The occurrence of powerful muscles solely for the purpose of an activity so little dynamic as supporting the head would not be justified by the mere prodigality of nature. The European bison, despite its enormous body weight, is distinguished by great agility, which is due, inter alia, to the capacity for sidewards movement of the vertebral column. The agility displayed by European bison in these movements is due to the intensive growth of $m$. splenius and $m$. semispinalis capitis. Both the topographical and structural properties of such muscles as $m$. iliocostalis and $m$. longissimus dorsi facilitate the animal's capacity for this type of movement.

As it is known, the somatic muscles include the outer muscles of the eyeball, which were elaborated in the case of European bison by Węgrzyn (1962). He investigated the details of the structure and insered. The study also contains a detailed description of the orbit and tions of these muscles and the nerve fibres with which they are providfasciae of the region.

The bone connections remain to be elaborated in order to complete the studies on the locomotory system of the European bison. Publications in this field include, in addition to the results of the investigations by Krysiak (1951) on ligamentum nuchae, the study by Węgrzyn \& S e r w a t k a (1961), dealing with ligamentum sacrotuberale latum of the European bison and of cattle. Among the features characteristic of the European bison the constancy of the vertebral insertion of the ligament, like that of the lateral caudal muscle, which exhibit variability in cattle, is noteworthy. It was found that the structure of the ligament is coarse-fibred and that there is a wide major sciatic foramen. The lumbosacral and iliolumbar angles are larger in the European bison than the corresponding angles in cattle. The pelvis of the European bison is therefore situated more horizontally.

The alimentary tract, in addition to the mention made of it in studies by Owen (1848), M üller (1852) and the monograph by W ró ble w ski (1927) has been dealt with in the Warsaw Centre in the comparative studies on the head section published by Wilk us (1957) to which we have already referred. A second publication on the alimentary tract is the study by Piękoś, Pilarski \& Roskosz (1958). Observations made on carcasses during the outbreak of foot-andmouth disease in 1953-1954 formed an attempt at utilizing material for 
anatomic purposes. The results obtained from observations of eleven fully-grown specimens provided data on the absolute and average length of the whole alimentary tract and its basic sections. In addition the ratio of intestinal length to body length in male and female bison was determined. Further research work being carried out in the Centre by P y t e l on the whole alimentary tract is now nearing completion.

Literature in previous years on the blood-vascular system was limited to the study, already referred to, by Poleine $\mathrm{r}$ (1932) and a certain number of references to the heart in European bison in the study by A lbrecht (1944). In 1966 We g r zyn completed the study entitled "The blood vascular system of the European bison", based on his investigation of 42 individuals. The scrupulously exact information in this elaboration excels even the information to be found on this subject in relation to the popular species of domestic animals. The pericardium in European bison is attached, in addition to the sternum, also to the diaphragm by means of a separate ligament. Descriptive characters and numerous measurements made of the heart in European bison show that it has a characteristic shape, like that of a broad-based low cone, distinctly flattened at the sides. The anterior margin of the heart in adult specimens is long and markedly convex, the posterior shorter and similar to a straight line in the course it takes. These relations are different in young European bison, in which the length of the two margins is at first similar. The right arterial cone is situated high up. The heart is relatively large, e.g. in males its average weight is $3.057 \mathrm{~kg}$, which forme $0.495 \%$ of the body weight. In the internal structure of the heart the complete closure of the oval foramen in individuals more than 42 days old is remerkable. The atrioventricular valves vary in number of cups of different size, from 3 to 7 in the right atrioventricular valve, and from 4 to 9 in the left. Both papillary muscles of the left ventricle usually have strong muscular fascicles running in the direction of the posterior wall of the ventricle, which end in the region of the left atrioventricular orifice.

The large arteries of the anterior section of the body, both the pulmonary and the systemic, have a diameter differing from that given for cattle, e.g. a. pulmonalis - average $46 \mathrm{~mm}$ (cattle $35 \mathrm{~mm}$ ), aorta $42 \mathrm{~mm}$ (cattle $31 \mathrm{~mm}$ ), a. subclavia $20 \mathrm{~mm}$ (cattle $12 \mathrm{~mm}$ ). The length of truncus brachiocephalicus com. is unexpectedly from 8,5 to $13 \mathrm{~cm}$ in the European bison, whereas in cattle it varies from 13 to $15 \mathrm{~cm}$. Many unrecorded vascular trunks were found which have not been described in cattle, e.g. aa. praesternalis, dorsalis linguae, mylihyoidea, circumflexa scapulae caudalis, recurrens tibialis, rami transversi scapulae and distinct division of rete mirabile cerebri into pars oralis et aboralis. Vascular trunks found in cattle such as a. stylomastoidea profunda, aa. digitales dorsales propriae, a. ureterica, as a branch of a. umbilicalis, are not found in European bison. In addition many other arteries in European bison exhibit differences in diameter, way in which they run from the heart, the course they take, division etc.

In addition to $v$. azygos sinistra a strongly developed $v$. azygos dextra usually occurs in European bison. It receives vv. intercostales dextrae from the anterior strongly developed section of the trunk and from the 
$v$. cervic. transv. dextra which is markedly vestigial in its further section.

Serwatka completed elaboration of the spinal nerves of European bison in 1966. Examination of the cadavers of 25 bison made it possible to grasp a large number of differences existing between European bison and domestic cattle. P ol e in e r ( $l$. c.), failed to reveal these differences in the nerve system of the legs, undoubtedly as the result of the scanty material at his disposal. The following must be mentioned among the characters typical of spinal nerves in European bison:

1. Absence of cutaneous branchings from the dorsal branches of the cervical nerves $I$ and $V I I I$ and thoracic $I$.

2. $N$. dorsalis scapulae runs from the ventral branches of the cervical nerves $I V-V I I$. It is represented by 4 powerful trunks and innervates the whole $m$. rhomboideus, and not only the cervical part of the muscle, as is the case in cattle. This is undoubtedly connected with the structure of $m$. rhomboideus typical of European bison, and with its functional properties.

3. $N$. subscapularis occurs in the form of two independent trunks.

4. NN . digitales dorsales of digit III (medialis et lateralis) and digit IV (medial) form a continuation of $n$. cutaneus antebrachii med., and to a minimum degree of $n$. radialis superficialis, which is the chief source of supply of fibre for these nerves in the case of cattle.

5. The participation of $n$. ulnaris in the innervation of $m$. flexor digitalis superfic. occurs far more frequently in European bison $(92 \%)$ than in cattle $(50 \%)$.

6. N. ilioinguinalis occurred in only $20 \%$ of the European bison examined.

The detailed description of the course and spread of different nerve trunks contained in the study under discussion is a valuable addition to the description of skeletal musculature and the muscles of the skin integument of European bison.

The latter has been discussed in the study by Pilarski (1962), which includes investigations of the skin, hair covering and c u t a n e o s g lands. The skin in European bison has a total surface greater than the average skin surface in cattle of the large breeds. The average for female European bison is $398 \mathrm{dcm}^{2}$, for cows 370 ; for male bison $478 \mathrm{dcm}^{2}$, for bulls 450 . The maximum total thickness of the skin is found on the neck along the medial dorsal line, on the lateral surfaces of the neck, on the sternum, base of the tail and the dorsal surface of the trunk. Distinct sex differences are found here also, of course predominating in favour of males. In all the regions given above the total thickness of the skin exceeds the corresponding data for cattle. Despite the considerable difference in absolute thickness of the skin, ratios of thickness of the epidermis to the thickness of the corium are observed to be similar to those in cattle. The structure of the corium in European bison is distinguished by clear demarcation of the papillary layer from the reticulate layer. The distribution of guard hair and wool hair in European bison takes the form of rows. The densest hair covering is situated on the head, neck, trunk and the gluteo-sacral region. The 
density of hair cover decreases in a peripheral direction on the legs. In addition to the densest covering and wool hair referred to above, long, sensitive hairs occur in European bison. The covering hairs are thicker in females than males, and the summer hairs usually thicker than those of the winter cost.

The morphology of the cuticulum of the hair covering is not typical of the species but depends on length of the hairs, place of origin and type of hair. The shorter the hair the denser the distribution of the cuticular cells. Two basic kinds of cutaneous glands occur in European bison, i.e. alveolar and tubular. Usually two alveolar glands and 1 tubular gland are combined in one hair follicle. The alveolar glands are ovoid and their surface smooth. The tubular glands are similar to those in cattle, but their secretory lumen attains greater dimensions (in cattle $150 \mu$, in European bison $180 \mu$ ). Their excretory duct is narrower than in cattle (in cattle $20 \mu$, in European bison $10 \mu$ ).

The short review of studies on the morphology of the European bison shows that the locomotion system has been investigated in the greatest detail. The completion of studies on the bone connections ends a certain stage in the knowledge obtained of this apparatus. The situation in relation to the blood-vascular system is similar, the microscopic structure of the heart and description of the main vascular trunks having been completed. It remains to elaborate the vascular system of different organs and the system of the portal vein. This will be partly solved by research on the alimentary tract which is nearing completion. Investigations of urinary organs and the male genital system are also well advanced. Elaboration of the genital organs of females will take longer in view of the fact that material for this purpose is more difficult to collect. Studies of the cranial nerves have been initiated, and also of certain questions relating to the structure of the central nervous system.

The Centre's plan for research on the respiratory, lymphatic, endocrine and vegetative nervous systems and some elements of the integumentum (horns, hooves) has not as yet been carried out. The milk gland, despite its small external dimensions, is sufficiently productive, and therefore it would be a question here of any particular features of the gland tissue, not only from the morphological but also physiological aspect.

\section{REFERENCES}

1. Albrecht R., 1944: Zur Anatomie des Bovidenherzens. Diss. Leipzig.

2. Bojanus H. L., 1827: De Uro nostrate eiusque sceleto commentatio. Nova Acta phys. Acad. Caes. Leopold.-Carol. Nat. Curios., 23, 2: 413-478. Bonnae.

3. Empel W., 1962: Morphologie des Schädels von Bison bonasus (L in n a e us, 1758). Bisoniana IV, Acta theriol. 6: 53-111. Białowieża.

4. Empel W. \& Roskosz T., 1963: Das Skelett der Gliedmassen des Wisents, Bison bonasus ( $\mathrm{L}$ in na e u s, 1758). Bisoniana X. Acta theriol. 7: 259-300, Białowieża. 
5. Flerov C., 1932: Obraz diagnostičeskih priznakov bialovežskih i kaukauskih zubrov. Izv. A. N. SSSR, 7, 10: 1579-1950, Leningrad.

6. Gilbert J. E., 1781: De Bisonte Lituanico. Vilnae.

7. J a n icki S., 1928: Badania nad szkieletem żubra (Bison bonasus L.). Prace roln.-leśne PAU, 27: 1-55, Kraków.

8. Juśko J., 1953: Dimorfizm płciowy szkieletu żubra (Bison bonasus L.). Folia morphol., 4: 1-30. Warszawa

9. Koch W., 1932: Uber Wachstums und Alterveränderung am Skelett des Wisents. Abt. Bayerisch. Akad. Wiss., Nath.-Naturw., Suppl.-Bd., 15: 555-678. München.

10. Koch W., 1934/35: The age order of epiphyseal union in the skeleton of the European bison (Bos bonasus L.). Anat. Rec., 61: 371-376.

11. Krölling O.. 1930: Über den Uterus masculinus, sowie einige Artmerkmale am Männlichen Genitalapparat des europäischen Wisents. Z. mikr. anat. Forsch., 20: 557-583. Leipzig.

12. Krysiak K., 1951a: Znalezisko dwóch czaszek prażubra, Bison priscus Boj. z ziem polskich. Wiad. arch., 18: 185-199. Warszawa.

13. Krysiak K., 1951b: Więzadło karkowe, ligamentum nuchae żubra (Bison bonasus). Folia morphol. 2: 271-283. Warszawa.

14. Krysiak K., 1960: The European Bison (Bison bonasus). State Council Conserv. Nat., 10: 1-38. Kraków.

15. Kulagin N., 1928: Gistologičeskoje strojene jaičnika zubra. Trudy Naučn. Isl. In-ta Zocl., 2: 5-58. Moskwa.

16. Leithner O., 1927: Der Ur. Bericht Int. Ges. Erhaltung d. Wisent, 2: 1-139. Berlin.

17. Millot J., 1945: Les bisons europeas des collections du Museum d'Historie Naturelle. Mammalia 9, 1: 1-19. Paris.

18. M ülle r F., 1852: Bemerkungen über den Aurochsen. Vierteljahrschr. Wiss, Vet.-kunde, 2: Wien.

19. Ow en R., 1848: Notes on the anatomy of the male aurochses (Bison europeus L.). Proc. zool. Soc. London, 16.

20. Piękoś M., Pilarski W. \& Roskosz T., 1958: Obserwacje nad długością jelita u żubra (Bison bonasus). Folia morphol. 9: 69-79. Warszawa.

21. Pilarski W., 1956: Deformacje kostne obserwowane na 6 okazach żubra (Bison bonasus L.). Folia morphol. 7: 301-306. Warszawa.

22. Pilarski W. \& Roskosz T., 1957: Zjawisko ukrzyżowienia (sacraiisatio) ostatniego kręgu lędźwiowego u samic żubra (Bison bonasus L.). Folia morphol. 8: 109-119. Warszawa.

23. Pilarski W., Serwatka S., Swieżyński K. \& Wẹgrzyn M., 1967: New attempts at fixing anatomical material of large mammals. Acta theriol., 12, 31: 453-458.

24. Pilarski W., 1962: Skóra i pokrywa włosowa żubra - Bison bonasus (L.). Diss. Warszawa.

25. Poleiner R., 1932: Der Anatomischen Aufbau der Extremitäten beim europäischen Wisent (Bison bonasus L.) in vergleich zum Hausrind. Diss. Wien.

26. Roskosz T. \& Empel W., 1961: The size of the head and the height of spinous processes in the region of the withers of the European bison, Bisoniana IV. Acta theriol. 5: 63-71. Białowieża.

27. Roskosz T., 1962: Morphologie der Wirbelsäule des Wisents, Bison bonasus (L inn a eus. 1758), Bisoniana VII. Acta theriol. 6: 113-164. Białowieża. 
28. Roskosz T. \& Empel W., 1963: Obserwacje L. H. Bojanusa nad czaszką i kręgosłupem żubra, Bison bonasus (L.) w świetle badań późniejszych. Przegląd zool., 7: 18-21. Wrocław.

29. S el a h a t $t$ in E., 1931: Haaruntersuchungen an einigen Boviden. Ztschr. Tierzucht. Züchtbiol., 211: 170-193. Berlin.

30. S erwatka S., 1966: Nerwy rdzeniowe żubra - Bison bonasus (L.). Diss. Warszawa.

31. Skiba J., 1834: Dissertatio inauguralis zootomica de osse hyoideo Uri. Vilnae.

32. S o k olov V., 1962: The structure and seasonal variability of skin in aurochses (Bison bonasus L.). Acta biol. cracov., zool., 5, 2: 295-302. Kraków.

33. Ś wieży ński K. \& Pilarski W., 1956: Umięśnienie skórne żubra. Folia morphol. 7: 133-138. Warszawa.

34. Swieżynski K., 1962: The skeletal musculatural system of the European Bison, Bison bonasus (L in n a us, 1758). Bisoniana VIII, 6: 155-218. Białowieża.

35. Węgrzyn M. \& Serwatka S.. 1961: Ligamentum sacrotuberale latum bei Bison bonasus (Linnaeus, 1758) und Bos taurus ( $\mathrm{L}$ inna e us, 1758). Bisoniana v̀, 5: 73-97. Białowieża.

36. We grzyn M., 1962: The orbit and extrinsic muscles of the eye of the European bison, Bison bonasus (L inna e us, 1758). Bisoniana IX, Acta theriol. 6: 219-237. Białowieża.

37. W ę grz y n M., 1966: Układ krwionośny żubra, Bison bonasus (L.). Diss. Warszawa.

38. Wilkus E., 1957: Porównawczo-anatomiczne badania nad głową żubra - Bison bonasus (L.). Cz. I Cavum oris. Acta theriol. 1: 183-307. Warszawa.

39. Z a r z y cki J., 1957: O budowie histologicznej niektórych narządów wewnetrznych żubra, Bison bonasus (L.). Zool. pol., 8: 53-64. Wrocław.

Received, February 24, 1967.

Warsaw Agricultur University,

Department of Animal Anatomy,

Warszawa, Grochowska 272.

\section{Kazimierz KRYSIAK i Krzysztof SWIERZYŃSKI}

\section{STAN BADAÑ NAD MORFOLOGIA ŻUBRA}

Piśmiennictwo anatomiczne dotyczące żubra nie jest bogate. Do roku 1949 ma ono w większości przypadków charakter przyczynków. Prace z tego okresu dotyczą głównie elementów kostnych, które rozsiane w różnych muzeach były łatwiejsze do przechowania od części miękkich i stanowiły material do badań nad tym gatunkiem.

Powstanie ośrodka badawczego nad anatomią żubra przy Katedrze Anatomii Zwierząt SGGW w Warszawie zapoczątkowano szereg badań w oparciu o liczniejszy niż dotychczas i udokumentowany material. Zokończono badania nad układem kostnym i umięśnieniem szkieletowym. Opracowano układ krwionośny, powłokowy i nerwy rdzeniowe. Na ukończeniu są prace nad układem pokarmowym i moczopłciowym. Całość wyników badań posłuży do monograficznego opracowania anatomii żubra. 